\title{
Comunicação no futebol: de reserva no banco a titular no ataque*
}

\author{
Communication in soccer: from reserve \\ on the bench to first-team forward
}

\author{
Comunicación en el fútbol: de reserva en \\ el banco a titular en el ataque
}

\section{Diego Figueiredo}

- Mestre em Administração de Empresas pela Universidade Federal de Minas Gerais (UFMG)

- Bacharel em Comunicação Social - Publicidade e Propaganda pela Pontifícia Universidade Católica de Minas Gerais (PUC-Minas)

- Professor do Instituto de Educação Continuada da PUC-Minas, no curso de PósGraduação de Gestão Estratégica de Negócios

- Sua linha de pesquisas engloba a profissionalização das organizações de futebol (estratégia, estrutura, ambiente organizacional, marketing e comunicação)

- dfigueiredoav@gmail.com

\section{José Coelho de Andrade Albino}

- Mestre em Administração de Empresas pela Universidade Federal de Minas Gerais (UFMG)

- Especialista em Semiótica e Teorias do Discurso pela Pontifícia Universidade Catrólica de Minas Gerais (PUC-Minas)

- Graduado em Administração - Comércio Exterior pela Faculdade de Ciências Gerenciais do Centro Universitário Una

- Professor da Faculdade de Comunicação e Artes da PUC-Minas

- Coordenador dos cursos de especialização em Marketing e em Gestão de Negócios do Instituto de Educação Coninuada da PUC-Minas

- Co-organizador do livro Cases de varejo: o mercado de consumo brasileiro por meio de experiências reais

- albino.albino@uol.com.br

* Participaram da pesquisa que originou este artigo: Frederico Luiz Barros, Frederico Heitmann, Igor Medeiros e Bruno Lage, todos publicitários formados pela PUC-Minas. 
Este artigo apresenta os resultados de uma pesquisa realizada com o objetivo de compreender o processo de projeção da identidade corporativa do Sport Club Internacional, de Porto Alegre (RS). Aborda, sobretudo, a forma como essa organização procura conciliar a ambiguidade dos labels de clube e empresa, principalmente na projeção de sua identidade na campanha publicitária "Alma colorada". O estudo conjuga os conceitos de visão, cultura nas organizações, identidade e imagem, com a abordagem da comunicação sob a ótica dos estudos culturais e da semiótica cultural. Trata-se, portanto, de uma pesquisa qualitativa de caráter descritivo que utiliza o método de estudo de caso.

PALAVRAS-CHAVE: BRANDING • IDENTIDADE • ESTUDOS CULTURAIS • FUTEBOL

Abstract

This article shows the results of a survey conducted with the purpose of understanding the process of projection of the corporative identity of Sport Club Internacional, of Porto Alegre (RS). It mainly addresses the way that the organization seeks to reconcile the ambiguity of the club and enterprise labels, principally in the projection of its identity in the "Alma colorada" (Crimson soul) advertising campaign. The study combines the concepts of vision, culture in organizations, identity and image, by addressing communication under the optics of cultural studies and of cultural semiotics. Thus, it concerns a qualitative survey of a descriptive nature that uses the case study method.

KEYWORDS: BRANDING • IDENTITY • CULTURAL STUDIES • SOCCER

Resumen

Este artículo presenta los resultados de una investigación realizada con el objetivo de comprender el proceso de proyección de la identidad corporativa del Sport Club Internacional, de Porto Alegre (RS). Aborda, sobre todo, la forma como esa organización busca conciliar la ambigüedad de las labels del club y empresa, principalmente en la proyección de su identidad en la campaña publicitaria "Alma colorada". El estudio conjuga los conceptos de visión, cultura en las organizaciones, identidad e imagen, con el abordaje de la comunicación desde la óptica de los estudios culturales y de la semiótica cultural. Se trata, por lo tanto, de una investigación cualitativa de carácter descriptivo, que utiliza el método del estudio de caso.

PALABRAS CLAVE: BRANDING • IDENTIDAD • ESTUDIOS CULTURALES • FÚTBOL 
0 futebol ocupa hoje um importante papel na "indústria do entretenimento", passando a ser visto como uma lucrativa oportunidade de negócios. A modernização da gestão dos clubes se mostra como a principal arma para conquistar e/ou)manter uma posição de destaque nessa nova configuração do esporte. Nela, não apenas os títulos estão em disputa, mas também os expressivos investimentos de patrocinadores e o alto retorno financeiro oriundo da comercialização de direitos de televisionamento, licenciamento, venda de jogadores, bilheteria de jogos, dentre outros itens.

No Brasil, essa concepção mercantil do esporte é relativamente recente quando comparada com a Europa, sendo a "Lei geral sobre desportos", conhecida como Lei Pelé, a primeira tentativa de regulamentar tais práticas (Proni, 1998). Essa lei afetou os clubes brasileiros, os quais ela previa transformar em sociedades civis com fins lucrativos ou sociedades comerciais. Ao longo do tempo, a Lei Pelé sofreu alterações e, atualmente, os clubes não têm mais a obrigatoriedade de mudar sua personalidade jurídica. Entretanto, vários deles começaram a adotar práticas empresariais, passando, inclusive, a promover a marca segundo os preceitos propostos pelas diferentes correntes teóricas do branding. Os clubes buscaram na publicidade e no marketing as ferramentas necessárias para projetar sua marca e, assim, ampliar a base de recursos. Porém surgiram diversos conflitos entre a identidade de clube e a de empresa (entende-se que o Internacional, por desenvolver práticas tanto comerciais quanto típicas de organizações sem fins lucrativos, passou a desenvolver duas identidades paralelas e coexistentes, conforme será explicitado a seguir na segunda corrente do branding), sendo que as lutas em torno dessa definição se tornaram constantes.

Nesse contexto, este estudo busca compreender o processo de projeção da identidade corporativa do Sport Club Internacional (Inter), um dos primeiros e mais bem-sucedidos clubes brasileiros a utilizar ferramentas de publicidade e marketing como forma de interação com seus torcedores e reforço da estratégia organizacional estabelecida. Destaca-se a forma como o Inter procura conciliar a ambiguidade dos labels de clube e empresa na campanha publicitária "Alma colorada". Para tanto, foi realizada pesquisa qualitativa de caráter descritivo, utilizando-se o método de estudo de caso único holístico (Yin, 2005).

\section{REFERENCIAL TEÓRICO}

\section{Compreendendo a identidade organizacional}

Segundo Schultz, Antorini e Csaba (2005), por branding entende-se o processo pelo qual as organizações se questionam continuamente sobre sua identidade com o objetivo de aumentar a competitividade. Os autores definem branding como a relação entre a origem da organização e as práticas diárias dos seus 
membros (cultura nas organizações); aonde a alta administração pretende chegar (visão estratégica); como a organização é percebida pelos stakeholders (imagem); tudo alinhado à forma como o conjunto do corpo funcional percebe que a organização seja (identidade).

O branding, de acordo com Schultz (2005), pode ser pensado a partir de duas correntes teóricas distintas. A primeira, denominada identidade corporativa, vem dominando o pensamento da disciplina e concebe a gestão de marcas a partir do produto, do marketing e da comunicação visual. Essa perspectiva enfatiza a criação de um posicionamento que diferencie a empresa no mercado de consumo, considerando a identidade como fruto de uma "escolha estratégica" da alta administração, devendo ser projetada, de forma racional e deliberada, interna e externamente. Já na segunda abordagem, denominada identidade organizacional, desenvolvem-se novas formas de compreender as práticas de gestão de marca, principalmente quando se analisam os processos comunicativos que a empresa estabelece com seus públicos.

Schultz (2005) afirma, ainda, que a visão de uma natureza estável e durável da identidade está sendo alterada para uma visão de processo, pois a identidade organizacional muda a partir da ressignificação dos valores que a constituem, processo este levado a cabo pelos stakeholders internos e externos. Ela tem, portanto, habilidade adaptativa a ambientes diversos e também frente às percepções que se modificam no tempo e no espaço. Logo, não deve ser pensada como essência inerente à corporação, porém como fluxo permanentemente construído. Ela parte da expressão de valores, porém as interpretações destes não são fixas nem estáveis. Elas são dinâmicas, mudando de acordo com diferentes contextos, grupos e épocas.

Moingeon e Ramanantsoa (1997, p. 385), representantes da escola francesa, definem identidade como o "conjunto de características interdependentes da organização que dá a ela especificidade, estabilidade e coerência, tornando-a identificável”. Porém, como esse padrão está em fluxo, não há estabilidade e permanência no tempo. Os autores argumentam, ainda, que a identidade é o produto da história vivida pela organização (estabilidade) e produtora dessa mesma história (mudança). Assim, ela comporta tanto os produtos simbólicos, como os mitos, tabus, ritos e projetos visuais, os quais constituem sua parte visível, quanto os valores tidos como verdade pelos membros da organização, que constituem a parte de difícil acesso.

Hatch e Schultz (1997) também informam que é a partir do material simbólico fornecido pela cultura organizacional que se constroem as imagens da organização. Entretanto, essas imagens são reabsorvidas pelo sistema cultural de significado da organização, sendo tomadas como artefatos culturais e usadas simbolicamente para inferir identidade. Complementando, as autoras argumentam que tanto a identidade como a imagem são (re)construídas a cada interação da empresa com seus stakeholders. 
Na primeira corrente, a imagem de marca é o reflexo da identidade de uma organização a partir da interpretação feita pelos diferentes públicos da empresa. Devido às possíveis diferenças encontradas entre esses públicos, uma organização pode ter diferentes imagens (Argenti, 2006). Já na segunda corrente, a imagem se forma não a partir do que a organização define como ideal, mas sim pela maneira como ela é percebida pelos seus públicos internos e externos. A imagem configura-se na mente das pessoas que têm contato com a organização, sendo (re)construída a cada interação; ela não é permanente, uma vez que seus stakeholders e suas respectivas interpretações acerca da identidade da empresa estão constantemente mudando (Gioia; Schultz; Corly, 2000).

Sillince e Jarzabkowski (2004) esclarecem que, apesar de existirem teorias sobre o gerenciamento de diferentes planos de identidade, elas são incompletas, pois não enfatizam como sua gestão poderia viabilizar o agir estratégico que é eminentemente tácito. Esses autores informam, ainda, que os estudos realizados até o momento sobre mudança identitária, geralmente, a concebem como uma construção, porém, nunca abordam a coexistência de múltiplos planos de identidade, principalmente se estes apresentarem incongruências entre si.

Para Sillince e Jarzabkowski (2004), não existe um plano de identidade certo ou errado para uma organização. Cada um resguarda um objetivo ou uma direção essencial para a identidade e estes não são necessariamente coerentes entre si. Entretanto, para que múltiplas facetas da identidade corporativa coexistam, beneficiando a organização, é indispensável que a mesma se torne flexível. Para tanto, os seus membros precisam ser capazes de acionar, estrategicamente, os labels que lhes possibilitem melhor alavancar os recursos organizacionais.

\section{Comunicação como prática cultural}

O papel da comunicação na primeira corrente do branding é o de projeção da identidade da organização para seus stakeholders, que ocorre por meio do envio, pelas organizações, de mensagens e símbolos que serão assimilados pelos públicos visados, constituindo-se, assim, sua(s) imagem(ns). Ela assume, nesse contexto, uma função meramente instrumental: os sujeitos, as intenções e, sobretudo, os conteúdos, sob a forma de mensagens, estão dados e a comunicação refere-se ao momento de seu transporte - sendo que ela é bem sucedida quando consegue produzir representações similares às do emissor no receptor (França, 2002). Nessa perspectiva, a comunicação funciona como elemento capaz de influenciar e controlar a(s) imagem(ns) das organizações, sendo esse controle o resultado de estratégias integradas e eficientes para expressão da identidade corporativa.

Os autores da segunda corrente adotam visão estratégica e interdisciplinar da comunicação, sendo a identidade organizacional não mais vista como algo 
acabado, mas permanentemente construída nas interações da empresa com seus stakeholders, assumindo o papel de construtora da realidade e responsável por envolver o cliente na cocriação da marca.

Ressalte-se que a comunicação passa a ser analisada como prática cultural a qual influencia, modifica e mobiliza a sociedade. Segundo Piedras e Jacks (2005, p. 200), a perspectiva dos estudos culturais permite que a publicidade seja abordada a partir das "relações entre a comunicação e a cultura, entre o texto e o contexto". Para tanto, essas autoras fazem uso do conceito de "articulação", desenvolvido por Stuart Hall e entendido como "um processo de criação de conexões”.

Pode-se pensar a publicidade também a partir da noção de fluxo, desenvolvida por Williams. Por meio desse conceito ressalta-se a forma sequencial de veiculação dos anúncios em diferentes suportes.

A respeito da análise de anúncios, Piedras (2005) destaca que ela não pode ocorrer de maneira isolada do contexto social, pois isso excluiria o papel de articulação da comunicação. O receptor não é visto como passivo diante das mensagens recebidas nem é determinado pelo contexto no qual está inserido, ainda que dele sofra influência. A mensagem, de recebida, passa a ser traduzi$\mathrm{da}$, e o receptor, ao interferir no sentido da mensagem, passa a fazer parte dela. Concluindo, Holt (1997) argumenta que o entendimento da publicidade migrou de "anúncios informativos" para ações publicitárias, as quais produzem sentidos a partir do acionamento de intertextos culturais que se encontram fora do anúncio. Enfatiza-se, portanto, que o sentido não está na coisa ou no objeto, porém surge na interação entre a organização e seus stakeholders.

\section{Comunicação e produção de sentido}

Bakhtin e Voloshinov (1979) afirmam que o pensamento de cada indivíduo pertence tanto ao sistema ideológico quanto ao seu psiquismo, estando, portanto, subordinado às leis específicas de cada um deles. Dessa forma, os autores não só ressaltam que existe uma inter-relação recíproca entre psiquismo e ideologia, mas também esclarecem que essa interação acontece de forma dialética. Assim, pode-se dizer que o sujeito se constitui a partir de uma ideologia que é anterior a ele e que lhe é trazida pelo discurso do outro. Entretanto, o sujeito faz suas escolhas com, por meio de ou apesar de toda a armadilha discursiva que lhe é transmitida. O discurso é laço social, estando implicado aí o resíduo ideológico do signo, mas também a denúncia significante. Denúncia de um lugar: o do sujeito da enunciação sustentado pela verdade de seu desejo.

Visando explicar como o sentido se constrói, Bakhtin e Voloshinov (1979) propõem uma diferenciação entre tema e significação, embora existam entre eles uma relação de complementaridade e mútua interação. Assim, o tema, 
considerado como singular e concreto, compreende o sentido inteiro de uma enunciação, à medida que envolve, além das formas linguísticas, aspectos não-verbais e contextuais. A significação, por sua vez, refere-se aos elementos que se repetem de forma igual em quaisquer enunciados nos quais são proferidos. Ela constitui, na visão de Keske (2004, p. 10), elo entre os comunicantes e se realizará quando estabelecido o diálogo entre os mesmos, a partir da compreensão ativa em meio a um contexto.

Nesse contexto, Faraco (2003, p. 71) esclarece que, para Bakhtin, "compreender não é um ato passivo (...), mas uma réplica ativa, uma resposta, uma tomada de posição diante do texto". O processo compreensivo não é, portanto, uma mera decodificação, mas uma resposta a um signo por meio de outros signos, o que evidencia a dimensão semiótica da comunicação. Assim, tem-se que o ato comunicativo é de natureza dialética, acontecendo entre sujeitos que assumem posições valorativas diante da mensagem. Essa tomada de posição axiológica diante do texto, segundo Faraco (2003), é o que permite uma atitude ativamente responsiva à palavra do outro, instaurando relações de sentido que geram significações a partir desse encontro de posições avaliativas.

Acrescentando, Pearce (1996) esclarece que o paradigma clássico da comunicação supunha que a linguagem se referisse ao mundo, tendo uma dimensão apenas representacional. Essas concepções foram superadas pelas noções construtivas da linguagem e da comunicação. "Dizer como algo se chama não é simplesmente nomeá-lo ou falar sobre isso: é, num sentido muito real, convocá-lo a ser como foi nomeado” (Pearce, 1996, p. 176). A principal função da comunicação é, portanto, a de construir mundos humanos, não simplesmente transmitir mensagens.

Insta ressaltar que o texto, segundo Barros (2003, p. 1), é "considerado hoje tanto como objeto de significação, ou seja, como um 'tecido' organizado e estruturado, quanto como objeto de comunicação, ou melhor, objeto de cultura, cujo sentido depende, em suma, do contexto sócio-histórico”. Já a intertextualidade consiste no "diálogo entre os muitos textos da cultura, que se instala no interior de cada texto e o define". A intertextualidade "não é mais uma dimensão derivada, mas, ao contrário, a dimensão primeira de que o texto deriva" (Barros, 2003, p. 4).

No que tange às formas de exteriorização da intertextualidade, Bakhtin e Voloshinov (1979) dispõem acerca de textos polifônicos e monofônicos. Nos primeiros, as vozes sociais interagem de forma expressa, enquanto nos últimos elas se escondem, embora existam em ambos, necessariamente, o dialogismo e a intertextualidade interna. Na visão de Carrascoza (2004, p. 2), os publicitários atuam em processo de criação, "cortando, associando, unindo e, consequentemente, editando informações que se encontram no repertório cultural da sociedade". É nesse momento de associação de ideias que o efeito mais ou menos explícito da intertextualidade se expressa, dependendo da intenção do criador. 


\section{METODOLOGIA}

Visando estudar o processo de projeção da identidade de clube-empresa por parte do Sport Club Internacional, realizou-se pesquisa qualitativa de caráter descritivo, utilizando o método de estudo de caso único holístico (Yin, 2005). Na primeira etapa da pesquisa foram feitos um levantamento e uma revisão de literatura em teses, dissertações, livros, periódicos científicos, artigos e sites da internet para aprofundar o estudo sobre as diferentes correntes teóricas do branding e da comunicação.

A escolha de um caso único se deve ao fato de o Inter ser, entre os clubes brasileiros, pioneiro no processo de profissionalização de sua gestão. É, também, o clube com maior número de sócios no país, sendo o maior na América do Sul e o sétimo no mundo. Destaca-se, também, o fato de o Inter fazer uso intensivo de publicidade e marketing, recurso ainda pouco explorado por outros clubes no país. Por fim, o clube consegue se destacar economicamente, mesmo não pertencendo ao eixo Rio-São Paulo onde os clubes recebem importância maior dos patrocinadores e da mídia.

Para a coleta de dados, foram realizadas, em abril de 2008, entrevistas dos tipos "narrativas" e "focada no tema da pesquisa" com os principais dirigentes do Inter (presidente, ex-presidente, vice-presidentes e diretores) e com profissionais da agência de publicidade e21, com destaque para os responsáveis diretos pela elaboração e execução das campanhas do clube entre 2006 e 2009 (Flick, 2004). Cabe salientar que este artigo, em função da limitação de espaço, aborda apenas a projeção da identidade de clube-empresa e análise de discurso da campanha "Alma colorada", conforme preceitos teórico-metodológicos propostos por Bakhtin e Voloshinov (1979) e Piedras e Jacks (2005). Além de um foco direcionado, as restrições de espaço impedem que partes relevantes das entrevistas realizadas, que foram gravadas e transcritas, sejam utilizadas neste artigo. A escolha daquela campanha se deve ao fato de ela ter sido a principal ação publicitária realizada pelo Inter depois de ele ter se tornado clube-empresa.

\section{APRESENTAÇÃO E ANÁLISE DOS DADOS}

\section{Trajetória do Sport Club Internacional}

O Sport Club Internacional foi fundado em Porto Alegre em 1909, pelos irmãos Poppe, filhos de imigrantes italianos. Após proibição de se associarem aos principais clubes da capital gaúcha, os Poppe's fundaram clube próprio com a política de aceitar qualquer pessoa, independentemente de raça, nacionalidade ou religião. A adoção de tal postura lhe rendeu o apelido de "o clube do povo". 
O clube só adquiriu força no âmbito nacional durante a década de 1970, quando venceu por três vezes o campeonato brasileiro. Durante as décadas de 1980 e 1990, o Inter passou por um período de derrotas. Mesmo vencendo a Copa do Brasil em 1992, foi o seu rival, Grêmio ${ }^{1}$, que conquistou importantes títulos. Em função dos maus resultados, o final da década de 1990 marcou um período caracterizado por dificuldades econômicas, pois as dívidas do clube aumentaram e ele, por duas vezes, quase foi rebaixado.

Entre 2002 e 2009, o Inter reorganizou-se internamente, fortaleceu-se financeiramente, saldou dívidas, investiu em patrimônio imobilizado e aumentou de maneira considerável sua receita. O clube foi certificado em dezembro de 2008 com a ISO 9001 pela gestão qualificada, sendo pioneiro no país na obtenção desse tipo de certificação. Como resultado de investimentos em marketing e campanhas publicitárias, o Inter aumentou seu quadro social de pouco mais de 7 mil associados em 2002 para 100 mil em 2009, colocando-se como o clube com maior número de sócios de toda a América e o sétimo em todo o mundo. Desde 2007, é o clube com o maior superávit financeiro do futebol brasileiro, o que lhe possibilitou investir em seu plantel de jogadores e em infraestrutura. Além dos resultados fora do campo, nesse período o Inter conquistou todos os títulos internacionais que um clube pode conquistar.

\section{Campanha "Alma colorada"}

Veiculada no primeiro semestre de 2006, a campanha "Alma colorada" teve como foco a disputa da Copa Libertadores da América. O objetivo principal foi convocar o torcedor para os jogos e clamar pelo seu apoio, afirmando que, para conquistar o campeonato, a atuação da torcida seria fundamental. Para tanto, o clube e sua agência de publicidade utilizaram diversos recursos gráficos e linguísticos que acionaram matrizes culturais as quais evocam as origens dos fundadores do clube e dos descendentes dos atuais torcedores.

Fernando Carvalho, presidente do clube na época, afirma que a campanha foi necessária para "fazer o torcedor acreditar" que era possível conquistar o título. Com essa visão, ele entrou em contato com a agência de publicidade e21, à qual informou um briefing sobre o que esperava da campanha. Porém, Fabrício Kichalowsky, diretor de criação da e21, entende que existiam posicionamentos diferentes sobre qual deveria ser o foco da campanha, afirmando que, num primeiro momento, o departamento de marketing do clube queria algo mais comercial. Essa diferença de pontos de vista pode ser entendida como um indício das lutas pelo poder dentro do clube, que transparecem nas negociações em torno da forma de projetar a identidade corporativa do clube.

\footnotetext{
1 Grêmio Foot-Ball Portoalegrense.
} 
Os anúncios analisados têm ilustrações simples e vetoriais, além de textos curtos. Eles possuem traços limpos, sem a utilização de texturas. As cores são chapadas, o que facilita a reprodução e leitura em mídias como o jornal, que foi mais explorado pelo clube. Além do apelo emocional, o texto também informa, quando inteira o torcedor sobre a data e o horário dos jogos. Ressalte-se que as margens do anúncio são delimitadas por moldura metálica com aspecto blindado. Esse elemento gráfico remete à simbologia de arma, fazendo, assim, uma alusão à guerra. O brasão exclusivo da campanha é colocado numa posição com maior destaque que o símbolo do clube. O aspecto metalizado, acompanhado pelas faixas utilizadas para escrever a frase "Libertadores 2006" também remete ao slogan "Agora é guerra".

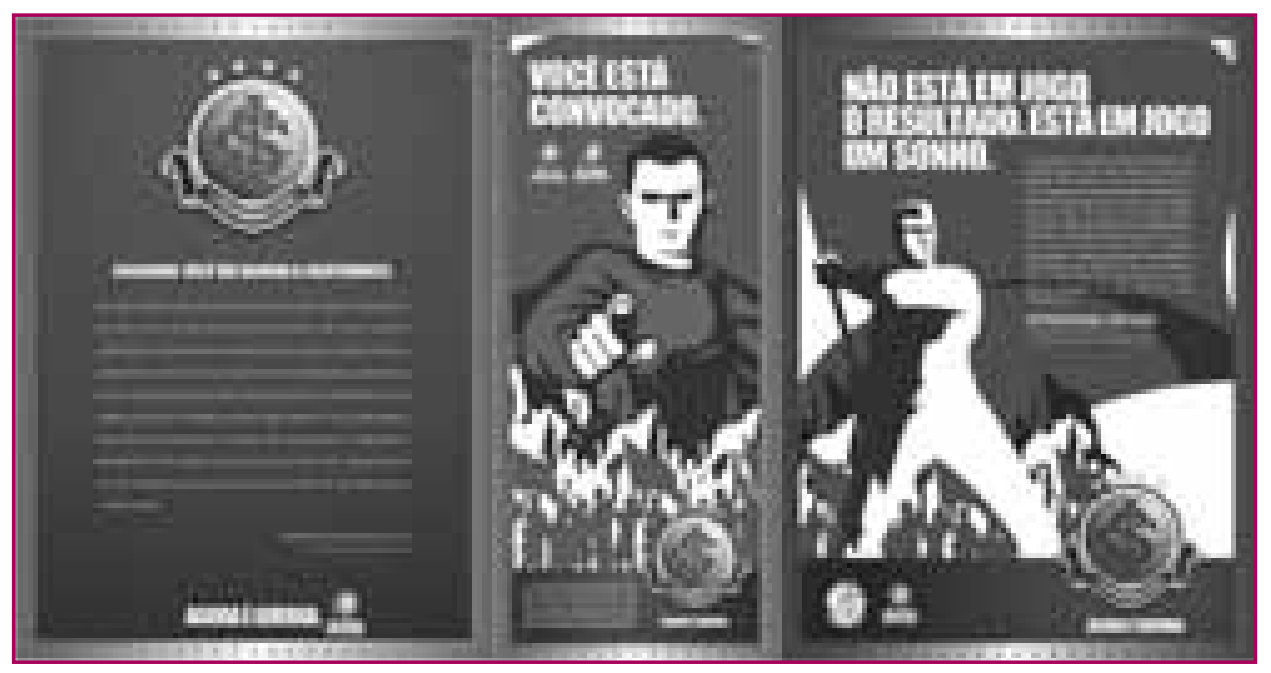

Figura 1: Peças da campanha "Alma colorada" Fonte: Agência e21

Os textos dos anúncios analisados sempre reforçam a ideia de que a participação do torcedor é fundamental; que está em disputa uma "guerra" e, por isso, todos devem se unir e acreditar na vitória. Ressalte-se que a frase "jogue junto" é usada nos três anúncios com esse objetivo. Também nesse sentido, o segundo anúncio apresentado na figura 1 convoca o torcedor para a "guerra" iminente cujo objetivo é conquistar o território inimigo; no caso em questão, busca-se conquistar a "América". No anúncio, percebe-se o destaque dado à figura central da peça, que é um torcedor apontando o dedo em postura eminentemente viril. Esse apelo relaciona-se, diretamente, com o tema "guerra", assim como com a cultura do futebol, um esporte que atrai principalmente homens, além de, indiretamente, reforçar que "a dominação é masculina” (Bourdieu, 2005). 
Nessas peças, assim como nas demais da mesma campanha, pode-se relacionar a cor vermelha ao sentimento de paixão que o torcedor alimenta em relação ao clube, assim como ao fascismo, ao comunismo e aos movimentos operários, matrizes culturais que estão nas origens italiana e operária dos fundadores do clube. De acordo com Fabrício Kichalowsky, os anúncios que possuem ilustração foram influenciados pela estética soviética que vigorou durante a revolução russa.

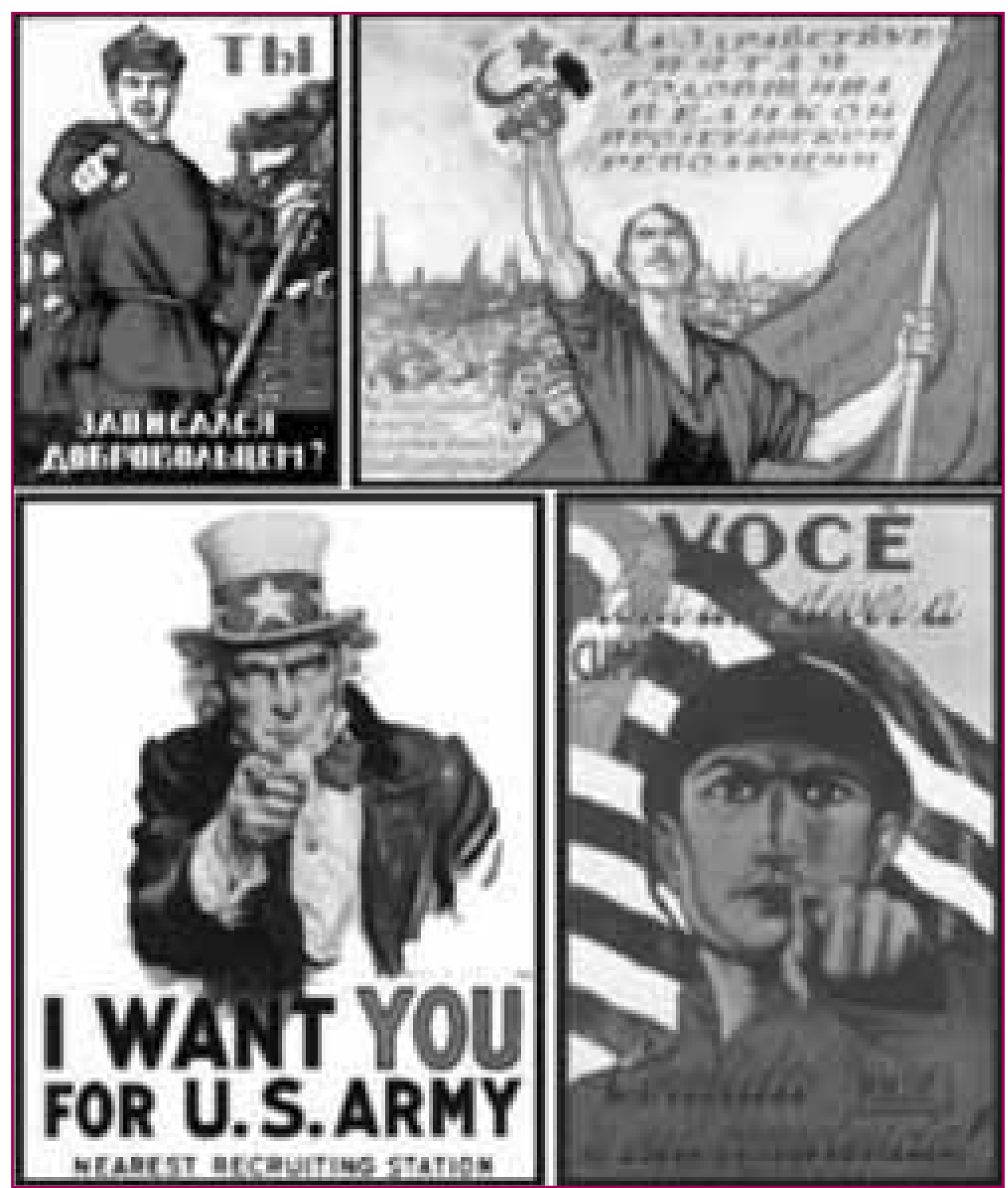

Figura 2: Referências utilizadas na criação da campanha "Alma colorada" Fontes: Sites www.pstu.org.br e images.google.com.br 
Comparando-se os anúncios do Inter com os cartazes soviéticos apresentados na figura 2, fica evidente a influência destes últimos no design gráfico, estilo argumentativo e conteúdo da campanha "Alma colorada". É possível afirmar, por exemplo, que o título da segunda peça colorada apresentada na figura 1 ("Você está convocado") é uma alusão ao título do cartaz russo ("Você já se alistou como voluntário?") apresentado na parte superior esquerda da figura 2. Além disso, a união do texto com a imagem do soldado apontando para o leitor tem forte semelhança com a do representante do clube convocando o torcedor.

No cartaz apresentado na parte superior direita da figura 2, um operário aparece, em primeiro plano, erguendo a bandeira vermelha, ao passo que, no segundo plano, se retrata uma multidão de operários, também carregando bandeiras vermelhas. Uma cena semelhante é utilizada no anúncio apresentado na figura 1 , onde um torcedor, posicionado em primeiro plano, brande a bandeira vermelha e, no fundo, outros torcedores também movimentam as suas flâmulas. Ressalte-se, ainda, a semelhança estética e de conteúdo entre os cartazes do recrutamento norte-americano para a Primeira Guerra Mundial, com a figura do Tio Sam, e o do levante revolucionário paulista (MMDC), ambos apresentados na parte inferior da figura 2, e as peças da campanha veiculada pelo Inter, especialmente com o segundo anúncio apresentado na figura 1. Em todas elas o texto verbal e as imagens são utilizados para fins de convocação, intimando o público a aderir à causa defendida, sendo o discurso sustentado por gritos de guerra, frases de efeito ou palavras de ordem, assumindo-se, assim, tom autoritário.

\section{CONSIDERAÇÕES FINAIS}

Este artigo buscou compreender o processo de projeção da identidade de clube-empresa do Sport Club Internacional e a forma pela qual o clube consegue gerenciar e alinhar esses diferentes planos de identidade. Ao estudar as estratégias de comunicação do Inter, tendo a segunda corrente do branding como referência, compreendeu-se a identidade como fluída, sendo constituída no embate entre as percepções dos membros da organização e a imagem formada por seus stakeholders.

Nota-se nos anúncios analisados que o Inter mantém vivos os valores que ele foi institucionalizando ao longo da sua trajetória, sendo esses labels fortalecidos a cada interação com os torcedores. Percebe-se que a alta direção do clube não tentou impor novos valores por meio de suas ações de comunicação. Mas, sim, resgatar e/ou)ressignificar labels da cultura organizacional que ela considerava capazes de acionar as matrizes culturais dos torcedores, visando à criação de vínculos não só comerciais, mas, principalmente, afetivos. Da mesma forma, os dirigentes do clube não acreditavam que as transformações no campo do futebol, impulsionadas pela Lei Pelé, requeriam mudança da identidade 
do clube, mas, sim, o gerenciamento de diferentes planos dessa identidade no sentido de promover maior adaptabilidade da organização.

Constatou-se, também, que o Inter se esforça, constantemente, para valorizar e convocar a participação do seu principal público: a torcida. Esta é entendida como coautora da trajetória de sucesso e da identidade do clube. Pode-se afirmar, também, que a mais importante característica do seu discurso é a ênfase na interação entre clube e torcedor. Em toda a campanha "Alma colorada", por exemplo, os apelos publicitários procuravam convocar o torcedor a participar da "guerra" pela Copa Libertadores da América.

Percebeu-se que o Inter compreende, pelo menos tacitamente, a comunicação não apenas como um instrumento mercadológico, mas sim como uma prática cultural. Mediante análise de suas ações de comunicação, foi possível compreender como o clube alinha cultura organizacional, visão e identidade corporativa. Já os dados coletados nas entrevistas realizadas com dirigentes do clube e profissionais de sua agência de publicidade permitiram concluir que as estratégias de marketing e comunicação do Inter sustentam-se em dois pilares: a conquista de títulos e o aumento do número de sócios.

Os dados também permitem afirmar que o Inter vem conseguindo alinhar a identidade de clube-empresa com a imagem que seus torcedores formam dele. Pode-se, mesmo, inferir que o discurso não é apenas compreendido, mas aceito entusiasticamente, o que se comprova, por exemplo, por meio dos resultados alcançados pela campanha "Alma colorada". O slogan "Agora é guerra” foi assumido pela torcida do clube, que passou a usar a frase em cartazes e bandeiras levados ao estádio. Além disso, durante a campanha, o clube aumentou consideravelmente o número de associados, visto que ao final do primeiro semestre de 2006 ele já possuía mais de 45 mil sócios. Depois da conquista da Libertadores, o número de sócios continuou crescendo, mesmo quando o clube não correspondeu dentro de campo. Hoje, o Inter é referência no que diz respeito à fidelização de torcedores em todo o mundo, tendo mais de 100 mil associados. E ainda, nos últimos cinco anos, a média de público presente nas partidas do clube subiu consideravelmente. Diante disso, pode-se concluir que as ações de comunicação, à medida que refletem a identidade e a cultura do Inter, fortaleceram a ligação entre o clube e seus torcedores.

Retomando o título do presente artigo, evidenciou-se que o Sport Club Internacional entende que, para se viabilizar como clube, precisa funcionar como empresa, mas, a fim de atingir seus objetivos de mercado, é necessário que sua identidade seja evocada por meio do acionamento das matrizes culturais dos seus públicos interno e externo. A comunicação é então utilizada como uma das principais ferramentas para que esse objetivo seja alcançado, buscando não apenas por meio da informação, mas da interação, uma posição cada vez mais competitiva no futebol brasileiro. 


\section{REFERÊNCIAS}

ARGENTI, Paul P. Comunicação empresarial: a construção da identidade imagem e reputação. 4. ed. Rio de Janeiro: Elsevier, 2006. $327 \mathrm{p}$.

BAKHTIN, Mikhail; VOLOSHINOV, Valentin N. Marxismo e filosofia da linguagem. São Paulo: Hucitec, 1979.

BARROS, Diana L. Pessoa. Dialogismo, polifonia, enunciação. In: BARROS, Diana L. Pessoa; FIORIN, José Luiz (Org.). Dialogismo, polifonia, intertextualidade. 2 ed. São Paulo: Edusp, 2003.

BOURDIEU, Pierre. A dominação masculina. 4. ed. Rio de Janeiro: Bertrand Brasil, 2005.

CARRASCOZA, João Anzanello. A. Razão e sensibilidade no texto publicitário. São Paulo: Futura, 2004.

FARACO, Carlos Alberto. Linguagem e diálogo. Curitiba: Criar, 2003.

FLICK, Uwe. Uma introdução à pesquisa qualitativa. Porto Alegre: Bookman, 2004.

FRANÇA, Vera Veiga. 0 objeto da comunicação/a comunicação como objeto. In: HOHLFELDT, Antonio Carlos.; MARTINO, Luiz Carlos; FRANÇA, Vera Veiga (Org.). Teorias da comunicação. Petrópolis: Vozes, 2002. p. 39-60.

GIOIA, Dennis A.; SCHULTZ, Majken; CORLEY, Kevin G. Organizational identity, image, and adaptive instability. Academy of Management, v. 25, n. 1, p. 63-81, 2000.

HATCH, Mary Jo; SCHULTZ, Majken. Relations between organizational culture, identity and image. European Journal of Marketing, v. 31, n. 5/6, p. 356-365, 1997.

HOLT, Douglas B. Poststructuralist lifestyle analysis: conceptualizing the social patterning of consumption in postmodernity. Journal of Consumer Research, v. 23, n. 4, 1997.

KESKE, Humberto. Dos sujeitos enunciadores e seus contextos dialógicos. In: CONGRESSO BRASILEIRO DE CIÊNCIAS DA COMUNICAÇÃO, XXVII, Porto Alegre, 30/08-03/09/2004. Anais... São Paulo: Intercom, 2004. Disponível em: <http://reposcom. portcom.intercom.org.br/handle/1904/17262>. Acesso em: 24 set.2007.

MOINGEON, Bertrand; RAMANANTSOA, Bernard. Understanding corporate identity. European Journal of Marketing, v. 31, n. 5/5, 1997.

PEARCE, Willie Bruce. Novos modelos e metáforas comunicacionais. In: SCHNITMAN, Dora Fried (Org). Novos paradigmas, cultura e subjetividade. Porto Alegre: Artes Médicas, 1996. p. 172 -187.

PIEDRAS, Elisa Reinhardt. Compreendendo o consumidor: as estratégias de mercado publicitário. In: CONGRESSO BRASILEIRO DE CIÊNCIAS DA COMUNICAÇÃO, XXIX, Brasília, 06-09/09/2006. Anais... São Paulo: Intercom 2006.

. A articulação da publicidade com o mundo social. Dissertação (Mestrado em Comunicação) - Universidade Federal do Rio Grande do Sul, Porto Alegre, 2005.

PIEDRAS, Elisa Reinhardt; JACKS, Nilda. A contribuição dos estudos culturais para a abordagem da publicidade. E-Compós Revista da Associação Nacional dos Programas de Pós-Graduação em Comunicação, v. 6, p. 1-16, ago. 2006.

. A publicidade e o mundo social. Contemporânea, v. 3, n. 2, p. 197-216, jul./dez. 2005.

PRONI, Marcelo Weishaupt. Esporte-espetáculo e futebol-empresa. Tese (Doutorado em Educação Física) - Universidade Estadual de Campinas, 1998.

SCHULTZ, Majken. A cross-disciplinary perspective on corporate branding. In: SCHULTZ, Majken; CSABA, Fabian F.; ANTORINI, Yun Mi (Ed.). Corporate branding: purpose/people/process. Copenhagen: CBS Press, 2005.

SILLINCE, John; JARZABKOWSKI, Paula. A process theory of multiple identity management and strategic action. In: EGOS COLLOQUIUM, Ljubljana, Slovenia, July 1-3, 2004. Annals... European Group of Organizational Studies, 2004.

SPORT. Sport Club Internacional. [s.I.]: [s.n.]. Disponível em: <http://www.internacional.com.br>. Acesso em: 18 dez. 2008.

YIN, Robert K. Estudo de caso. Porto Alegre: Bookman, 2005.

Recebido em: 31.08.2011 / Aceito em: 01.11.2011 